\title{
Core elements affecting sharing evidence from the European Union
}

\author{
Olga Lingaitienè ${ }^{1}$, Virginija Grybaitė ${ }^{2}$ and Aurelija Burinskiené ${ }^{3, *}$
}

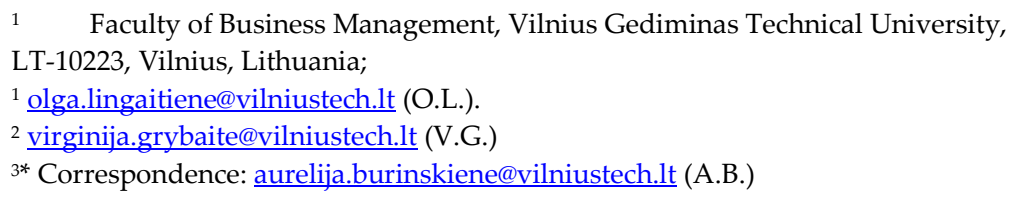

\begin{abstract}
Sharing activity is getting higher attention due to increasing popularity in recent years. In the paper, the authors investigated the main elements affecting the sharing activity. (1) Literature review: The theoretical part starts from the revision of definitions of sharing activity; description of the links between sharing and sustainable development, policy recommendations and relevant regulation in the field; later on, the study emphasises the key elements important for sharing. Finally, the authors investigated how the Covid-19 pandemic affected sharing activity; (2) Methods: During empirical research, the authors revised the list of 37 variables. The study uses data for each of the 27 EU countries from 2011 to 2020. The authors investigated correlation between macroeconomics variables to determine key variables for the regression model; (3) Results: The authors constructed a dynamic regression model that can be applied to predict the number of participants visiting sharing platforms in the European Union (EU); (4) Conclusions: The study shows that seeking to forecast the number of visits to sharing platforms it is necessary to use values of main macroeconomic variables such as consumer price index, productivity index, total unemployment rate, the number of users and households connected to the Internet, etc.
\end{abstract}

Keywords: sharing activity, Covid-19 impact, core elements, sustainable development

\section{Introduction}

Economic and social systems that provide access to goods, services, data and talent without ownership are called sharing (otherwise known as collaborative consumption). All systems operate on the basis of information technology and peer-to-peer communities, where individuals can distribute, share and reuse overcapacity and obsolete (or rarely used) assets. All systems come in a variety of forms.

Sharing is spreading rapidly across Europe and across a wide range of sectors. Shared consumer services such as home-sharing, car-sharing for domestic use are already known and used by many people in the EU. Collaborative consumption offers many new opportunities for citizens and innovative entrepreneurs. A distinctive feature of cooperative consumption is that service providers are usually private individuals who offer their assets or services, sometimes based on cooperation. More and more micro-entrepreneurs and small businesses are using collaboration platforms.

A survey conducted by Eurostat in 2019 showed that $21 \%$ of EU citizens used a website or an app to arrange accommodation from another person and $8 \%$ have done the same for transport services. In the tourism sector, collaborative consumption provides many exciting opportunities for citizens as consumers as well as for micro-entrepreneurs and SMEs.

Despite the fact that collaborative consumption offers new opportunities for entrepreneurs and more choice for consumers, there are rules and obligations that citizens and businesses need to be aware of. Applicable EU rules and policy recommendations to help citizens, businesses and EU countries take full advantage of new business models and 
promote sustainable business development and collaborative consumption are explained in the EU 2016 June Communication on the European Agenda for the collaborative consumption.

It is sometimes very difficult for existing market operators to succeed in collaborative platforms. However, platforms enable individual citizens to offer their services, as well as promoting new employment opportunities, flexible working arrangements and new sources of income. Collaborative consumption for consumers can provide benefits through new services, an extended supply, and lower prices.

The study starts from the literature and reglamentation review, later introduces the core elements, discuss Covid-19 aspects on sharing and ends with empirical research whose purpose was to identify macroeconomic variables important for sharing activity. Finally, the authors provide the discussion part and conclusions.

\section{Literature Review}

The EU have common goals: increasing resource efficiency, creating jobs and supporting micro-entrepreneurship, increasing community participation and fostering digital innovation (European Commission, 2016). It is an opportunity to unite in pursuit of common priorities and to integrate a stronger, more resilient Europe (European Commission, 2016).

The Sharing model offers more opportunities to adapt to our needs to use assets more efficiently at a lower cost (Curtis \& Mont, 2020; Daunorienè et al., 2015).). It revolves around three models:

2.1. Product-based Systems: Without product ownership, users pay for the benefits of using the product (e.g., by sharing a car/bike). Such a model undermines traditional industries based on individual private ownership models.

2.2. Redistributing Markets: Redistribution of second-hand goods from those who do not want them to those who want them (e.g., barter markets and second-hand goods). In diferent markets, products may be free (Freecycle), others may be exchanged (thredUP) or sold (eBay).

2.3. Collaborative Lifestyles: When people with similar needs or interests come together and share less tangible assets such as time, space, skills, and money. These include jobs (CitizenSpace), gardens (Landshare) or car parks (ParkatmyHouse), loans between individuals (Lending Club) and housing rentals (Airbnb and Couchsurfing).

Given the loose definitions of sharing, many have adopted a flexible and open approach to the topic.

A definition of the sharing is "business models where activities are facilitated by collaborative platforms that create an open marketplace for the temporary usage of goods or services often is provided by private individuals (Piscicelli et al., 2018).

According to the EU definition, sharing is a business model where activities are facilitated by collaborative platforms that create an open marketplace for the temporary usage of goods or services often provided by private individuals (European Commission, 2015). As the European Commission 2ecognizes in offering such definition "The term of collaborative consumption is often interchangeably used with the term 'sharing activity'. Sharing is a rapidly evolving phenomenon and its definition may evolve accordingly" (European Commission, 2016; European Parliament resolution, 2014; Probst et al., 2015a; Probst et al., 2015b; Probst et al., 2015c).

Vaughan \& Hawksworth, 2014 replied on the definition of PriceWaterhouseCoopers $(\mathrm{PwC})$ the "sharing uses digital platforms to allow customers to have access to, rather than ownership of, tangible and intangible assets" (Vaughan \& Hawksworth, 2014). In addition to typical examples such as Uber and Airbnb, the definition also includes productive collaborations, as well as Spotify subscription models for content and music entertainment (Botsman, 2013; Selloni, 2017; Ertz, 2020, Huang, 2021).

Mody et al., 2019 argue that sharing is a promising phenomenon due to many economic, social, and technological factors. Geissinger et al. (2019), Cheng et al. (2020) argue that sharing promotes efficiency, community, and sustainability by focusing on servicing 
untapped resources, and (Muduli et al., 2020) argue that sustainability is a major business concern.

De las Heras et al. (2020) stated that sharing is not a "fragile and temporary trend", and it has a significant influence on reversing competition around the world by offering opportunities for many small services providers to access the market. Olson \& Kemp (2015) identified the main benefits of sharing for consumers, such as: adapting to the needs of individuals, rather than reacting to the changes in demand; offering unique experiences that commercial providers cannot ensure and lower prices compared to commercial providers. Furthermore, various researchers (for example, de Leeuw \& Gössling, 2016; Huarng, 2018; Wu \& Zhi, 2016; Zhu \& Liu, 2020) underlined the reduction of consumers' costs as the main benefit of sharing. According to Piscicelli et al. (2018), sharing is advantageous to the environment, as it makes greater use of existing resources and the potential energy savings that would result from car and bike-sharing (Heinrichs, 2013; Martin, 2016). Furthermore, Schor \& Wengronowitz (2017) state that sharing is less resource-intensive.

According to Toni et al. (2018), the sharing encourages resource efficiency, waste reduction, and lower consumption to promote sustainable consumption practices (Martin, 2016). Furthermore, energy savings as an advantage of the sharing is underlined by Skjelvik et al. (2017), Curtis \& Lehner (2019), Curtis \& Mont (2020). Schor (2010) emphasised that social innovations and new technologies could improve people's lives and protect the Earth planet. Huarng (2018), Mauri et al. (2018) state that the sharing creates new opportunities for entrepreneurs and consumers, provides the flexibility of access to goods, and increases consumer choices; it offers broader and cheaper access to services for customers in the short term (Acquier et al., 2017).

According to Harvey et al. (2017), sharing is a potential new path to sustainability (Heinrichs, 2013). Kaushal (2018), Muñoz \& Cohen (2017) state that sharing promotes sustainable growth and energy efficiency. Furthermore, it can be argued that sharing is closely related to sustainability (Hossain, 2020; Dabbous \& Tarhini, 2021), and the benefits of sharing correspond to the dimensions of sustainable development: economic, social and environmental (Böcker \& Meelen, 2017; Wagner \& Strulak-Wojcikiewicz, 2020; StrulakWójcikiewicz \& Wagner, 2021); sharing contributes to sustainable development goals by promoting sustainable consumption and provides growth opportunities for innovative start-ups (European Commission, 2015). Furthermore, Räisänen et al. (2020) stressed that sharing could promote sustainability and is a pathway to circularity (Geissdoerfer et al., 2017).

There is no consensus on what activities are part of the "sharing". According to Botsman (2013); what is now called "sharing" has also been called "collaborative consumption". Other authors name other parts of the "sharing". For a more extensive overview, see Table 1. 
Table 1. Alternative names of the sharing

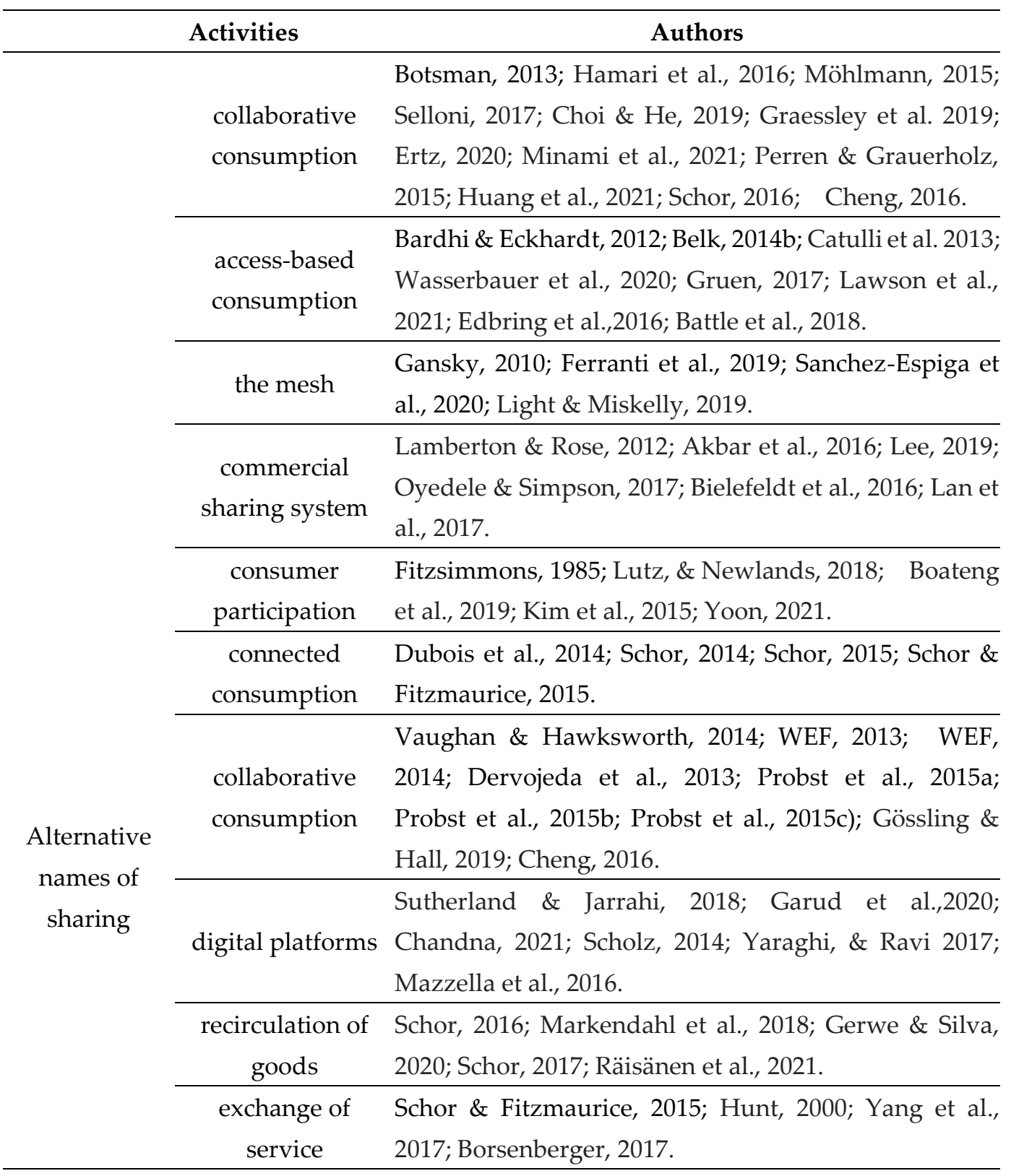

According to the European Parliament, "the sharing or collaborative consumption, is a new socio-economic model that has taken off thanks to the technological revolution, with the internet connecting people through online platforms on which transactions involving goods and services can be conducted securely and transparently" (European Parliament resolution, 2015). The Internet and connectivity technologies have made it possible to bring together demand and supply in a broad spectrum of markets (Becchis et al., 2019). Various researches, e.g., Molenaar (2015), Dervojeda et al. (2013), Hamari et al. (2015), Daunorienė et al. (2015), Demailly \& Novel (2014), Selloni (2017), Dabbous \& Tarhini (2019), Huckle et al. (2016) stated that technological factors are the most significant factors stimulating the growth of sharing.

According to Baller et al. (2016), the Internet is one of the most critical general-purpose technologies globally, that impacts all activities linked to the Internet. Baller et al. (2016) emphasised the ability of Information and Communication Technology (ICT) to improve access to services and enhance connectivity. Therefore, ICT is one of the most critical factors that determine the growth of sharing. Therefore, it can be stated that the level of network infrastructure and access to ICTs is crucial for the development of sharing. The Internet and mobile technology stimulate the growth of a vast online marketplace. Technology has enabled an easy and more convenient way to interact with others, to share 
idle assets with others. Evans \& Gawer (2016) emphasised the importance of such technical elements as big data analytics, low-cost cloud storage, social media users' growth, and the increased use of mobile devices to develop sharing. The latest technologies can maintain vast amounts of data concerning people and assets, ensuring continued sharing. Secure payment systems provide a safe and convenient way to transfer money between sharing parties, i.e. between providers and users of services. The Internet of Things (IoT) has a significant impact on the development of sharing by enabling owners of the resources to be connected remotely. According to Huckle et al. (2016), the Internet of Things and blockchain technology (Acquier et al., 2017) open opportunities to create peer-to-peer secure automatic payment mechanisms and foreign exchange platforms. The latest technologies provide impetus to spread sharing by facilitating peer to peer business models (CIO review, 2016).

\section{Sharing reglamentation in the EU}

In 2015, the European Commission (EC) adopted the Single Market Strategy and declared the development of the European Agenda for collaborative consumption. As a result, "A European Agenda for Collaborative Economy" was published in 2016 and aimed to "support consumers, businesses and public authorities to engage confidently in this rapidly evolving landscape". It should be noted that collaborative consumption either is a part of the Digital Single Market Strategy presented in 2016. In addition, the Communication on Online Platforms (2016) highlights the importance of online platforms, including sharing platforms, for further developing digitalisation in the EU.

Although the term "collaborative consumption" was used in the report, European Commission acknowledges that the terms "collaborative consumption" and "sharing" can be used interchangeably. The report defines sharing as "business models where activities are facilitated by collaborative platforms that create an open marketplace for the temporary usage of goods or services often provided by private individuals." Sharing encompasses service providers, service users and internet platforms, which act as intermediaries connecting providers with users. Service providers can be private individuals offering services occasionally or service providers acting in their professional capacity (European Commision, 2016). Furthermore, it was stated that transactions in the sharing generally do not involve a change of ownership. However, some transfer of intellectual property ownership could be possible in the sharing. Hence, it can be argued that if individuals sell used things through platforms, such as transactions cannot be classified as part of the sharing. Therefore, it could be argued that e-commerce cannot be considered a part of collaborative consumption platforms.

The European Agenda for Collaborative Economy amplified the contribution of the sharing to job creation and growth, emphasised the emergence of new opportunities for consumers and entrepreneurs and the potential of the sharing to contribute to competitiveness and growth. Collaborative consumption (or sharing) is recognised as a new, innovative, dynamic sector in which consumers may benefit through new services, increased supply, and lower prices. However, the European Commission indicates that policy recommendations and adequate regulations are needed to help EU countries benefit from the sharing and promote balanced development. The critical areas required for regulation emphasised in "A European Agenda for Collaborative Economy" are market access, consumer protection, liability, labour law, and taxes.

European Commission documents state that technological, economic and societal factors drive collaborative consumption (Commission Staff Working Document, 2016). However, it should be noted that political-legal factors are not mentioned as essential factors in developing a sharing activity. Meanwhile, it is acknowledged that the regulatory environment impacts sharing development. Therefore, the authors of this article argue that technological, economic, social-demographical and political-regulatory factors are essential for the development of sharing activity. 


\section{COVID-19 impact on sharing}

There is currently little academic literature that analyzes and describes the impact of a Covid-19 pandemic on various aspects of life, including sharing. This pandemic has shown both how much the sharing helped consumers access essential goods and services, while at the same time revealing the very real restrictions and regulations that undermine them.

According to Hossain (2021), the Covid-19 has affected sharing platforms, service providers, and service receivers (customers) along with governments. Evelyn (2020), says Covid-19 has disproportionately affected vulnerable groups and millions of people involved in sharing have lost their livelihoods. Curtis and Mont (2020); Mont et al. (2020) note that some service providers may believe that they should be treated as employees, but profits and social welfare in a sharing are controversial issues.

In response to the Covid-19, it was important for the platforms to update their websites. According to Willison (2020), until the physical sites were closed, platform owners have been working to redesign their online infrastructure and physical space, including "... moving to better hosting websites, mail server upgrade to solve spam problems, introduced the inventory stocks of consumables, vendor management software.

Hossain (2021) notes that understanding the impact of the Covid -19 pandemic on the sharing activity is crucial. Particularly significant changes in Covid -19 have led to accommodation and transport sectors. According to Tardivo (2020), both passenger and freight transport have experienced severe declines due to the Covid-19 crisis. The carriage of passengers within the EU Member States and between the European Union and the rest of the world has been partially or completely closed (Shortall et al., 2021). Land transport was also disrupted and slowed down due to additional sanitary checks at the border.

According to Farmaki et al. (2020), during the pandemic, there has been a significant increase in online networking platforms (P2P) through which individuals can rent out unused real estate for a short period. Property owners benefit from a variety of benefits: they offer guests comfortable and affordable accommodation that is usually more authentic and more localized than hotel accommodation. P2P hosting offers entrepreneurial opportunities, extra income, and hosts get satisfaction from their hospitality service.

Zhang et al. (2021) and based on the World Transport Conference the Research Society (WCTRS) there is a platform for transport researchers, managers, policy makers and educators around the world to exchange ideas, surveyed the impact of Covid-19 and provided such many restrictions: many institutions were closed in all countries and/or regions: factories $(44.7 \%)$ and shops $(34.2 \%)$, and people who could restrictions have been closed, travel $(40.1 \%)$ and travel frequency $(15.1 \%) .17 .6 \%$ of cities/towns were not allowed and emergency medical care $(56.3 \%)$, medical care $(50.7 \%)$ were allowed.

As described by many researchers, quarantine has harmed the transport and accommodation sectors. However, activities in other sectors of the sharing, such as freelance work, streaming services and online delivery, have flourished. Batool et al. (2020) note that the use of the Internet and food delivery services has increased during the Covid-19 pandemic. The closure of offices has increased the demand for freelance work. With the closure of cinemas, video streaming services such as Netflix, Disney + and Amazon Prime have become the main source of entertainment, with subscriptions and usage of all streaming services increasing dramatically (Koetsier, 2020).

E-commerce has fundamentally changed the structure of trading goods. Currently, $55 \%$ of the world's population shop online regularly. The penetration of internet-enabled devices and the increasing number of online stores have led to an inevitable change within the retail landscape. Naturally, this has also had a tremendous influence on shopping behaviours. Nowadays, there are two major ways for a retailer to bring products or services to market - online and offline. The online sales channel refers to the purchase of physical goods via the internet - on a desktop of the personal computer, tablet or smartphone. The offline sales channel covers all purchases in stationery stores, via telesales or mailorder 
(e.g. print catalogues). The online market for pharmaceuticals varies considerably by country because legislations on over-the-counter pharmaceuticals differ widely from country to country. Thus, the online share in Europe and Asia in 2019 is 12\%.

\section{Key elements in studies focusing on sharing}

The business models of sharing services are very different from each other. To identify the key elements behind the development of business models of sharing, the authors have examined studies by different researchers in the field of sharing and its links to key elements synergy. Table 2 provides descriptions of the sharing of other researchers, highlighting key trends in the field.

Table 2. Authors researching sharing

\begin{tabular}{|c|c|}
\hline $\begin{array}{l}\text { Authors } \\
\text { researching } \\
\text { sharing }\end{array}$ & Description of study \\
\hline $\begin{array}{l}\text { Dabbous } \quad \& \\
\text { Tarhini, } 2021\end{array}$ & $\begin{array}{l}\text { \& The sharing uses technology, information and marketing that fosters a new culture for resour } \\
\text { efficiency customers prefer access to ownership. }\end{array}$ \\
\hline $\begin{array}{l}\text { Daunorienè } \\
\text { al., } 2015\end{array}$ & $\begin{array}{l}\text { et Increased availability of technology for hosting an online market drives the growth of sharin } \\
\text { activity. }\end{array}$ \\
\hline $\begin{array}{l}\text { Demailly } \\
\text { Novel, } 2014\end{array}$ & $\begin{array}{l}\text { \& Internet resale, gift, exchange, short term rental and borrowing platforms are available the par } \\
\text { of the real sharing that is renewed due to digital technology development. }\end{array}$ \\
\hline $\begin{array}{l}\text { European } \\
\text { Commission, } \\
2016\end{array}$ & $\begin{array}{l}\text { Collaborative platforms enable individuals to offer services, promote new employment } \\
\text { opportunities, flexible working arrangements and new sources of income. Collaborative } \\
\text { consumption encourages consumers to share more wealth and use resources more efficiently. }\end{array}$ \\
\hline $\begin{array}{l}\text { Hamari et al } \\
2015\end{array}$ & $\begin{array}{l}\text { ICT has grown into a "collaborative consumption": accessing, providing or sharing access to } \\
\text { goods and services on a peer-to-peer basis, coordinated through community-based online } \\
\text { service. }\end{array}$ \\
\hline Huarng, 2018 & $\begin{array}{l}\text { Proposes a conceptual framework for the application } \\
\text { increase the efficiency of long-term care by increasin }\end{array}$ \\
\hline $\begin{array}{l}\text { Huckle et al } \\
2016\end{array}$ & $\begin{array}{l}\text { Internet of Things and blockchain technology benefit from sharing applications and creating a } \\
\text { ryriad of sharing applications, such as peer-to-peer automatic payment mechanisms, foreign } \\
\text { exchange platforms, digital rights management. }\end{array}$ \\
\hline \multicolumn{2}{|c|}{$\begin{array}{l}\text { Muñoz \& Cohen The increasing diversity of sharing business models and the implications for business growth } \\
2017 \quad \text { community impact, sustainability and public policy. }\end{array}$} \\
\hline \multicolumn{2}{|c|}{$\begin{array}{l}\text { Piscicelli et al., Describes digital platform facilitation (P2P) sharing of underutilized assets, identifying } \\
2018 \\
\text { possible reasons for commercial success or failure. }\end{array}$} \\
\hline Räisänen, 2020 & $\begin{array}{l}\text { Consumer trust and consumer and platform trust are at the heart of the sharing - explorin } \\
\text { how to uncover trust issues in sharing platforms. }\end{array}$ \\
\hline $\begin{array}{l}\text { Schor } \quad \& \\
\text { Wengronowitz, } \\
2017\end{array}$ & $\begin{array}{l}\text { Sharing activity, also known as "collaborative consumption", is seen as a progressive, } \\
\text { disruptive force that makes economies more efficient and distributes value to consumers. }\end{array}$ \\
\hline Toni et al., 2018 & onsumer perspective using sharing platforms. \\
\hline
\end{tabular}




Wagner \&

Strulak- It is investigated how technological solutions in sharing platforms influence the use of Wojcikiewicz, collaboration platforms.

2020

Commercial Sharing Systems (CSS) provide access to the benefits of a product without Akbar et al., 2016 ownership. Describes the possibility of creating attractive CSS for the target materialistic user segment.

Bardhi \& Access-based consumption is examined in the context of the sharing activity as the nature of Eckhardt, 2012 the exchange, its use and the platform itself.

The growth of e-commerce has increased interactive distribution through various channels,

Castillo et al., Crowdsourced Logistics (CSL), which simulates a delivery service to 1,000 customer locations 2018 in a dynamic market environment compared to traditional delivery. Goal CSLs will bring strategic benefits to businesses.

Describes multifunctional digital platforms that can be used for crowdfunding financial

Chandna, 2021 resources, creative ideas, to collaborate and pool a wealth of non-financial resources, focusing on the mission of social change.

Three broad areas of the sharing activity are revealed: sharing business models and their

Cheng, 2016 impact, the nature of sharing and the development of sharing sustainability, and two areas examining the impact of sharing on travel and tourism services.

With the development of platform technologies, collaborative consumption (P2P-CC) is Choi \& He, 2019 gaining popularity in the sharing activity. P2P-CC is shown to double a company's profits compared to users without P2P-CC. The platform benefits from a revenue-sharing scheme rather than a flat-rate service taxation scheme.

The sharing is going on at the intersection of the three most important economic trends: mutual

Frenken, 2017 exchange, ownership, and circulation business models. Examined the environmental impact of online sharing platforms and possible prospects, one of which is monopoly super platforms.

The challenges faced by companies in the sharing activity based on the digital platform are Garud et al., 2020 being addressed to validate their business models by examining the dynamics that have emerged since the introduction of the sharing business model.

The concept of sharing is compared to the wider collaborative consumption and its social, Gössling \& Hall, economic, environmental and political implications concerning the goals of sustainable 2019 development are discussed. Digital platforms turn global corporations into intermediaries, control most profits and profit from them.

Found that circularity and sharing have significant links in terms of sustainability, business Henry et al., 2021 models, sustainability consumption and management. Interfaces are revealed mainly in the business spheres platform and service-based activities.

Different types of sharing services are analyzed, recurring patterns, similarities, and Markendahl et differences between different types of sharing services are identified. Commercial, or al., 2018 community, service provider platforms with user fees or free, open or closed access are examined. 
Sutherland \&

The sharing is reviewed through transactions in digital spaces. The role of digital platforms in Jarrahi, 2018 sharing has been identified. The concept of platform mediation provides a set of essential opportunities for sharing technologies.

According to Owyang (2013), social networking technologies, mobile technologies, and payment systems are the main technological drivers. Social networking technologies are essential for social profiles and reputation tracking. Mobile technologies with locationsensing technologies allow one to establish user location, essential for transportation. The latest technologies have also been described as 'disruptive technologies' crucial to the emergence of sharing. The Communication "Digitising European industry reaping the full benefits of a digital single market" indicates how the Internet, the Web and recent developments in technology reshape business models, transform the business landscape and people's life and enable the growth of sharing (Communication from the Commission, 2016). With the rise of digital technology and the Internet, information costs fell sharply and coordination costs for sharing activities dropped correspondingly.

\section{Methodology and research methods}

The study aims to identify the main macroeconomic factors, to develop a regression model. Selected variables from the publicly available Eurostat database for the period 10 years 2011-2020. are taken to analyze dynamic interactions. To identify linear connections, the authors took 37 macroeconomic variables for the $27 \mathrm{EU}$ countries and identify how the population of these countries visits 10 sharing platforms (AirBnB, BlaBlaCar, eBay, Fiverr, Gumtree, Kickstarter, Lime, Uber, UpWork, and Vinted). For this set of data, the authors tested the significance of correlation. Later, statistically insignificant variables were removed, and the procedure is applied only to 15 macroeconomic variables, whose variance probability is significant for visiting sharing platforms.

The authors apply a linear regression model. The authors use a simple regression analysis procedure to convert the regression coefficients into a model depicting a linear relationship between the dependent and the regressors.

This analysis reveals dynamic trends and allow assumptions about the existence (non-existence) of relationships in pairs. The authors of the dependent variables selected the number of visits to sharing platforms for which data for the last month of the year was collected from Google Trends (2020) (Google trends, 2021).

The regression model was developed to estimate how macroeconomic variables affect the number of visits to sharing platforms:

$$
\begin{gathered}
\operatorname{sep}_{t}=\beta_{0}+\beta_{1} c p i_{(t)}+\beta_{2} h c i_{(t)}+\beta_{3} i h i_{(t)}+\beta_{4} i i u_{(t)}+\beta_{5} i o g \\
\beta_{7} \operatorname{tur}_{(t)}+u_{t}
\end{gathered}
$$

where

$\operatorname{sep}_{t}$ - logarithmic dependent variable of the number of customers visits to sharing platforms in EU countries in year $t$,

$\beta_{0}$ - intercept,

$c p i_{(t)}-$ dlog of consumer price index in EU countries in year $t$;

$h c i_{(t)}-\mathrm{d} \log$ of the number of households connected to the Internet in EU countries in year $t$;

$i h i_{(t)}$ - dlog of the number of the Internet users seeking health information in EU countries in year $t$;

$i i u_{(t)}$ - dlog of the number of individuals, which use the Internet in EU countries in year $t$

$\operatorname{iog}_{(t)}-\mathrm{d} \log$ of the number of individuals using the Internet for ordering goods or services in EU countries in year $t$;

$l p p_{(t)}$ - dlog of productivity index (when real labour productivity per person, is used assuming that 2010=100) in EU countries in year $t$;

$\operatorname{tur}_{(t)}$ - dlog of the total unemployment rate (percentage of the total population) in EU countries in year $t$; 
$u_{t}$ - random model error,

$\beta_{1}, \beta_{2}, \beta_{3}, \beta_{4}, \beta_{5}, \beta_{6}, \beta_{7}-$ coefficients of elasticity reflecting the influence of independent variables on sharing.

The authors delivered a specific regression model, which results into:

$$
\begin{aligned}
& \operatorname{sep}_{t}=-485.98+4.51 c p i_{t}-3.70 h c i_{t}+3.22 i h i_{t} \\
& +3.47 \text { iiu }_{t}-2.05 \operatorname{iog}_{t}-2.58 \operatorname{lpp}_{t}-8.04 \text { tur }_{t} \\
& \text { 1.55) } \\
& \text { (2.04) (-1.71) }
\end{aligned}
$$

The correlation coefficient of the formed regression model is 0.82 , and the adjusted $\mathrm{R} 2$ is 0.76 . The provided model is placed in Fig. 1 .

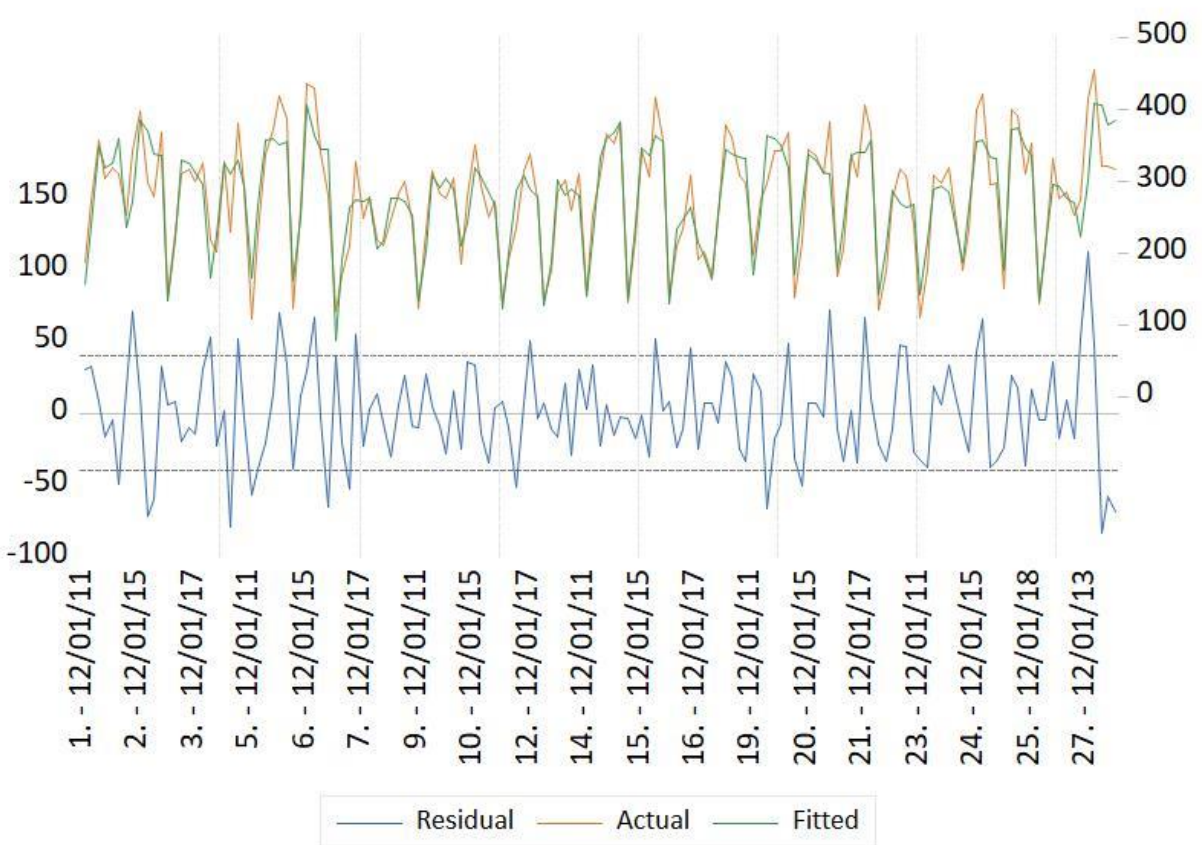

Figure 1. The forecasting of the number of visits to ten sharing platforms at the EU countries. Source: constructed by the authors.

The authors performed statistical validity tests. Probability $t$ and probability $\chi 2$ in the test statistics do not indicate significant autocorrelation and heteroskedasticity. All other results of the performed dynamic regression analysis are provided in Table 3.

Table 3. Statistical validity

\begin{tabular}{lc}
\hline \multicolumn{1}{c}{ Indicators of statistics } & Values \\
\hline 1. Formation of regression model & \\
Durbin Watson statistics & 2.28 \\
\hline 2. Residual Cross-Section Dependence Test & \\
Bias-corrected scaled LM & 0.53 \\
$\quad$ Statistics & 0.59 \\
Probability & \\
Pesaran CD & -1.58 \\
Statistics & 0.11 \\
Probability & \\
\hline
\end{tabular}


This proves that other values are also very important in the study of the number of visits to sharing platforms, not included in the early studies for sharing. The authors found that variables such as a consumer price index, productivity index, unemployment rate, internet users are critical and affect the number of visits to sharing platforms. The data provides a pattern and is normalized using a logarithmic process.

\section{Discussion}

The authors researched sharing activities, that have recently been developing across the world. Due to its higher focus on sharing sustainable development compared with traditional activities, it is important to research and clarify how we could stimulate environment-friendly activity.

The previous study of the authors was dedicated to the US market and this study focus on the EU landscape. The statistic describing each market is a bit different, so the results stating which variables are important for sharing are a bit different. However, the authors could mention that for researching the US market -71 variables were investigated. However, for the research of sharing in the EU market, the number of variables was half lower. What is interesting, is that the authors included the Covid-19 topic, also to the investigation thematic, as two years of the pandemic are already visible in statistics.

The results can be useful for practitioners and policymakers exploring the promotion of sharing activities. Such activity has been evident for a long time as online platforms have contributed to wider accessibility. However, sharing is still a new area of research and a little number of studies have been carried. Thus, the authors attempted to explore the phenomenon of knowledge sharing and conceptual level expansion.

\section{Conclusions}

In the study, the authors identified that such macroeconomic variables as a consumer price index, productivity index, total unemployment rate, the number of users and households connected to the Internet are critical and affect the number of visits to sharing platforms in the EU countries.

The scientific literature analyzing the growth of sharing activities lacks research on quantitative factors that ensure the development trends and opportunities of the sharing economy. The number of visits to sharing platforms and the number of sharing platforms is growing. Even in countries that have focused on sharing activities from the outset, data suggest that predicting the size of the sharing market or the growth of sharing platforms is not easy. During this investigation of sharing activity, the authors tried to fill the gap, as scientific literature lacks deep analysis on sharing activity and its growth.

The literature review shows strong research development in the direction of revising technological factors. The study expands knowledge in this area.

The authors investigated the number of critical elements required to visit sharing platforms and presented a linear regression model. The model is useful for predicting the number of visits using monthly data. As sharing is still a new field of research and little research has been done, the authors have tried to explore the phenomenon of sharing and expand the conceptual level of knowledge. The authors introduced a composite index and compared its links with other indices, such as the consumer price index, the producer price index, and the business production sentiment index, and provided a tool to predict the number of visits to sharing platforms.

The research has certain limitations, so the research can be extended to other directions:

- Review of the index of visits to sharing platforms in other countries;

- Analysis of additional components;

- Review of different periods.

In addition, other directions for predicting visits to sharing platforms could be included in the composite index setup.

Author Contributions: Conceptualization and statistics, O.L. and V.G.; methodology, A.B.; updates, O.L.; formal analysis, V.G.; writing-review and editing, A.B. 


\section{Appendix}

Correlation between macroeconomics variables

\begin{tabular}{|c|c|c|c|}
\hline $\begin{array}{l}\text { The number of visits to sharing } \\
\text { platforms }\end{array}$ & Abbrevation & Statistics & ASP \\
\hline \multirow[t]{2}{*}{ Business freedom } & $\mathrm{BF}$ & Corr. Coeficient & 0,09 \\
\hline & & Probability & 0,3 \\
\hline \multirow[t]{2}{*}{ Consumer price index } & CPI & Corr. Coeficient & 0,40 \\
\hline & & Probability & 0,0 \\
\hline \multirow[t]{2}{*}{ Cultural And Social Norms } & CSN & Corr. Coeficient & 0,16 \\
\hline & & Probability & 0,1 \\
\hline \multirow[t]{2}{*}{ Entrepreneurial Intention } & EI & Corr. Coeficient & $-0,10$ \\
\hline & & Probability & 0,2 \\
\hline \multirow{3}{*}{$\begin{array}{l}\text { Fixed broadband subscriptions (per } 100 \\
\text { people) }\end{array}$} & & & \\
\hline & FBS & Corr. Coeficient & 0,33 \\
\hline & & Probability & 0,0 \\
\hline \multirow[t]{2}{*}{ Government effectiveness } & GE & Corr. Coeficient & 0,15 \\
\hline & & Probability & 0,1 \\
\hline \multirow{2}{*}{$\begin{array}{l}\text { GDP per capita, PPP (current } \\
\text { international \$) }\end{array}$} & $\mathrm{CPC}$ & Corr Cooficiont & 0.12 \\
\hline & GPC & $\begin{array}{l}\text { Corr. Coeficient } \\
\text { Probability }\end{array}$ & $\begin{array}{r}0,12 \\
0,1\end{array}$ \\
\hline \multirow{3}{*}{$\begin{array}{l}\text { Households - type of connection to the } \\
\text { internet }\end{array}$} & & & \\
\hline & $\mathrm{HCI}$ & Corr. Coeficient & 0,48 \\
\hline & & Probability & 0,0 \\
\hline \multirow[t]{2}{*}{ Households - level of internet access } & HIA & Corr. Coeficient & 0,40 \\
\hline & & Probability & 0,0 \\
\hline \multirow[t]{2}{*}{ Investment freedom } & IF & Corr. Coeficient & 0,15 \\
\hline & & Probability & 0,1 \\
\hline \multirow{2}{*}{$\begin{array}{l}\text { Internet use finding information about } \\
\text { goods and services }\end{array}$} & & Corr. Coeficient & 0,36 \\
\hline & IFI & Probability & 0,0 \\
\hline \multirow[t]{2}{*}{ Internet use seeking health information } & IHI & Corr. Coeficient & 0,34 \\
\hline & & Probability & 0,0 \\
\hline \multirow[t]{2}{*}{ Internet use Internet banking } & IIB & Corr. Coeficient & 0,20 \\
\hline & & Probability & 0,0 \\
\hline \multirow[t]{2}{*}{ Individuals - internet use } & IIU & Corr. Coeficient & 0,31 \\
\hline & & Probability & 0,0 \\
\hline \multirow{2}{*}{$\begin{array}{l}\text { Mobile internet access (percentage of } \\
\text { individuals) individuals used a mobile } \\
\text { phone(or smart phone) to access the } \\
\text { internet }\end{array}$} & IMP & Corr. Coeficient & 0,61 \\
\hline & & Probability & 0,0 \\
\hline \multirow{2}{*}{$\begin{array}{l}\text { Individuals using the internet for } \\
\text { ordering goods or services }\end{array}$} & IOG & Corr. Coeficient & 0,33 \\
\hline & & Probability & 0,0 \\
\hline \multirow[t]{2}{*}{ Last online purchase in the 12 months } & IPO & Corr. Coeficient & 0,34 \\
\hline & & Probability & 0,0 \\
\hline
\end{tabular}




\begin{tabular}{|c|c|c|c|}
\hline $\begin{array}{l}\text { Individuals using the internet for selling } \\
\text { goods or services, percentage of } \\
\text { individuals }\end{array}$ & ISG & Corr. Coeficient & 0,17 \\
\hline \multirow[t]{2}{*}{$\begin{array}{l}\text { Internet use participating in social } \\
\text { networks }\end{array}$} & ISN & Corr. Coeficient & 0,41 \\
\hline & & Probability & 0,0 \\
\hline \multirow[t]{2}{*}{ Internet use telephoning or video calls } & ITC & Corr. Coeficient & 0,28 \\
\hline & & Probability & 0,0 \\
\hline \multirow{2}{*}{$\begin{array}{l}\text { Individuals using the Internet (\% of } \\
\text { population) }\end{array}$} & & & \\
\hline & IUI & $\begin{array}{l}\text { Corr. Coeficient } \\
\text { Probability }\end{array}$ & $\begin{array}{r}0,26 \\
0,0\end{array}$ \\
\hline \multirow[t]{2}{*}{ Labour costs (wages and salaries total) } & $\mathrm{LC}$ & Corr. Coeficient & 0,16 \\
\hline & & Probability & 0,1 \\
\hline \multirow{2}{*}{$\begin{array}{l}\text { Productivity (Real labour productivity } \\
\text { per person, Index, 2010=100) }\end{array}$} & LPP & Corr. Coeficient & 0,32 \\
\hline & & Probability & 0,0 \\
\hline \multirow{3}{*}{$\begin{array}{l}\text { Mobile-cellular subscriptions per } 100 \\
\text { inhabitants }\end{array}$} & & & \\
\hline & MCS & Corr. Coeficient & 0,00 \\
\hline & & Probability & 1,0 \\
\hline \multirow[t]{2}{*}{ Individuals - mobile internet access } & MIA & Corr. Coeficient & 0,35 \\
\hline & & Probability & 0,0 \\
\hline \multirow[t]{2}{*}{ Population density } & PD & Corr. Coeficient & 0,04 \\
\hline & & Probability & 0,6 \\
\hline \multirow[t]{2}{*}{ Property rights } & PR & Corr. Coeficient & 0,24 \\
\hline & & Probability & 0,0 \\
\hline \multirow[t]{2}{*}{ R\&D expenditure (\% of GDP) } & RDE & Corr. Coeficient & 0,22 \\
\hline & & Probability & 0,0 \\
\hline \multirow[t]{2}{*}{ Rule of law } & ROL & Corr. Coeficient & 0,16 \\
\hline & & Probability & 0,0 \\
\hline \multirow[t]{2}{*}{ Regulatory quality } & $\mathrm{RQ}$ & Corr. Coeficient & 0,13 \\
\hline & & Probability & 0,1 \\
\hline \multirow[t]{2}{*}{ Tax burden } & $\mathrm{TB}$ & Corr. Coeficient & $-0,13$ \\
\hline & & Probability & 0,1 \\
\hline \multirow{2}{*}{$\begin{array}{l}\text { Total unemployment rate ( percentage of } \\
\text { the total population) }\end{array}$} & TUR & Corr. Coeficient & $-0,31$ \\
\hline & & Probability & 0,0 \\
\hline \multirow{2}{*}{$\begin{array}{l}\text { Ratio of young people in the total } \\
\text { population on } 1 \text { January by sex and age } \\
\text { (from } 15 \text { to } 29 \text { ), percentage }\end{array}$} & YP & Corr. Coeficient & $-0,29$ \\
\hline & & Probability & 0,0 \\
\hline
\end{tabular}

\section{References}

1. Acquier, A., Daudigeos, T., \& Pinkse, J. (2017). Promises and paradoxes of the sharing economy: An organising framework. Technological Forecasting and Social Change, 125, 1-10. https://doi.org/10.1016/j.techfore.2017.07.006 [Google Scholar]

2. Ahmad, N., \& Schreyer, P. (2016). Measuring GDP in a digitalised economy. [Google Scholar] 
3. Akbar, P., Mai, R., \& Hoffmann, S. (2016). When do materialistic consumers join commercial sharing systems. Journal of Business Research, 69(10), 4215-4224. [Google Scholar]

4. Bai, C., \& Yu, B. (2021). Research on the value co-creation of the crowdsourcing services under the sharing economy. The International Journal of Electrical Engineering \& Education, 0020720920984007. [Google Scholar]

5. Baller, S., Dutta, S., \& Lanvin, B. (2016). The Global Information Technology Report 2016. Innovating in the Digital Economy. World Economic Forum, Geneva. [Google Scholar]

6. Bardhi, F., \& Eckhardt, G. M. (2012). Access-based consumption: The case of car sharing. Journal of consumer research, 39(4), 881-898. [Google Scholar]

7. Batool, M., Ghulam, H., Hayat, M. A., Naeem, M. Z., Ejaz, A., Imran, Z. A., \& Gorun, T. H. (2020). How COVID-19 has shaken the sharing economy? An analysis using Google trends data. Economic Research-Ekonomska Istraživanja, 1-13. [Google Scholar]

8. Battle, A., Ryding, D., \& Henninger, C. E. (2018). Access-based consumption: a new business model for luxury and secondhand fashion business?. In Vintage Luxury Fashion. Palgrave Macmillan, Cham. 29-44. [Google Scholar]

9. Becchis, F., Postiglione, M., Valerio, S. (2019). Regulating the Platform Economy: Problems, Challenges, Tools. Network Industries Quarterly, 21(3), 12-16. https://www.network-industries.org/wp-content/uploads/2019/09/ Regulating-thePlatform-Economy-Problems-Challenges.pdf

10. Belk, R. (2014). You are what you can access: Sharing and collaborative consumption online. Journal of business research, 67(8), 1595-1600. [Google Scholar]

11. Bielefeldt, J., Poelzl, J., \& Herbst, U. (2016). What's mine Isn't yours-barriers to participation in the sharing economy. Die Unternehmung, 70(1), 4-25. [Google Scholar]

12. Boateng, H., Kosiba, J. P. B., \& Okoe, A. F. (2019). Determinants of consumers' participation in the sharing economy: A social exchange perspective within an emerging economy context. International Journal of Contemporary Hospitality Management. Vol. 31 No. 2, pp. 718-733. [Google Scholar]

13. Böcker, L., \& Meelen, T. 2017. Sharing for people, planet or profit? Analysing motivations for intended sharing economy participation. Environmental Innovation and Societal Transitions, 23, 28-39. https://doi.org/10.1016/ j.eist.2016.09.004 [Google Scholar]

14. Borsenberger, C. (2017). The Sharing Economy and the "Uberization" Phenomenon: What Impacts on the Economy in General and for the Delivery Operators in Particular?. In The Changing Postal and Delivery Sector. Springer, Cham, 191203. [Google Scholar]

15. Botsman, R. (2013). The sharing economy lacks a shared definition. Fast Company, 21, 2013. [Google Scholar]

16. Brečko, B., Ferrari, A., Vuorikari, R., \& Punie, Y. (2016). The digital competence framework for consumers. Joint Research Centre Science for Policy Report. [Google Scholar]

17. Broeder, P., \& Crijns, K. (2019). Self-disclosure and trust on Airbnb: a cross-cultural perspective. Storytelling across platforms: Managing corporate and marketing communications from a storytelling perspective, 160-171. [Google Scholar]

18. Buheji, M. (2020). Sharing economy and communities attitudes after covid-19 pandemic-review of possible socio-economic opportunities. American Journal of Economics, 10(6), 395-406. [Google Scholar]

19. Castillo, V. E., Bell, J. E., Rose, W. J., \& Rodrigues, A. M. (2018). Crowdsourcing last mile delivery: strategic implications and future research directions. Journal of Business Logistics, 39(1), 7-25. [Google Scholar]

20. Catulli, M., Lindley, J. K., Reed, N. B., Green, A., Hyseni, H., \& Kiri, S. (2013). What is Mine is NOT Yours: Further insight on what access-based consumption says about consumers. In Consumer culture theory. Emerald Group Publishing Limited. [Google Scholar]

21. Chandna, V. (2021). Social entrepreneurship and digital platforms: Crowdfunding in the sharing-economy era. Business Horizons. [Google Scholar] 
22. Cheng, M. (2016). Sharing economy: A review and agenda for future research. International Journal of Hospitality Management, 57, 60-70. [Google Scholar]

23. Cheng, M., Chen, G., Wiedmann, T., Hadjikakou, M., Xu, L., \& Wang, Y. (2020). The sharing economy and sustainabilityassessing Airbnb's direct, indirect and induced carbon footprint in Sydney. Journal of Sustainable Tourism, 28(8), 1083-1099. [Google Scholar]

24. Choi, T. M., \& He, Y. (2019). Peer-to-peer collaborative consumption for fashion products in the sharing economy: Platform operations. Transportation Research Part E: Logistics and Transportation Review, 126, 49-65. [Google Scholar]

25. Choi, T. M., Taleizadeh, A. A., \& Yue, X. (2020). Game theory applications in production research in the sharing and circular economy era. International Journal of Production Research, 58(1), 118-127. [Google Scholar]

26. CIO review. 2016. How technological advancements are beneficial for sharing economy. Retrieved from http://www.cioreview.com/news/how-technological-advancements-are-beneficial-for-sharing-economy-nid-18307-cid15.html

27. Commission Staff Working Document accompanying the document. Communication From the Commission to the European Parliament, The Council, The European Economic and Social Committee and The Committee of The Regions - A European agenda for the collaborative economy. European agenda for the collaborative economy - supporting analysis (COM (2016) 356 final).

28. Communication from the Commission to the European Parliament, the Council, the European Economic and Social Committee and the Committee of the regions. Online Platforms and the Digital Single Market. Opportunities and Challenges for Europe. (SWD (2016) 172 final)). https://eur-lex.europa.eu/legal-content/ EN/TXT/?uri=CELEX\%3A52016DC0288

29. Communication from the Commission to the European Parliament, the Council, the European Economic and Social Committee and the Committee of the regions. Digitising European Industry Reaping the full benefits of a Digital Single Market. SWD (2016) $110 \quad$ final. $\quad \underline{\text { https://eur-lex.europa.eu/legal-content/EN/TXT/HTML/?uri=CELEX:52016 }}$ DC0180\&from $=$ EN

30. Curtis, S. K., \& Lehner, M. (2019). Defining the sharing economy for sustainability. Sustainability, 11(3), 567, 1-25. https://doi.org/10.3390/su 11030567 [Google Scholar]

31. Curtis, S. K., \& Mont, O. (2020). Sharing economy business models for sustainability. Journal of Cleaner Production, 266, 121519, 1-15. https://doi.org/10.1016/j.jclepro.2020.121519 [Google Scholar]

32. Dabbous, A., \& Tarhini, A. (2021). Does sharing economy promote sustainable economic development and energy efficiency? Evidence from OECD countries. Journal of Innovation \& Knowledge, 6(1), 58-68. https://doi.org/ 10.1016/j.jik.2020.11.001 [Google Scholar]

33. Daunorienè, A., Drakšaitè, A., Snieška, V., \& Valodkienè, G. (2015). Evaluating sustainability of sharing economy business models. Procedia - Social and Behavioral Sciences, 213, 836-841. https://10.1016/j.sbspro.2015. 11.486 [Google Scholar]

34. De las Heras, A., Relinque-Medina, F., Zamora-Polo, F., \& Luque-Sendra, A. (2020). Analysis of the evolution of the Sharing Economy towards sustainability. Trends and transformations of the concept. Journal of Cleaner Production, 125227. https://doi.org/10.1016/j.jclepro.2020.125227 [Google Scholar]

35. De Leeuw, T., \& Gössling, T. (2016). Theorising change revisited: An amended process model of institutional innovations and changes in institutional fields. Journal of Cleaner Production, 135, 435-448. https://doi.org/10.1016/j.jclepro.2016.06.119 [Google Scholar]

36. Demailly, D., \& Novel, AS (2014). The sharing economy: make it sustainable. Studies, 3(14.1). Retrieved from: https://www.iddri.org/en/publications-and-events/study/ sharing-economy-make-it-sustainable [Google Scholar]

37. Denning, S. (2014). An economy of access is opening for business: five strategies for success. Strategy E Leadership. [Google Scholar] 
38. Dervojeda, K., Verzijl, D., Nagtegaal, F., Lengton, M., Rouwmaat, E., Monfardini, E., \& Frideres, L. (2013). The sharing economy. Accessibility based business models for peer-to-peer markets. Retrieved from http://www.eukn.eu/ fileadmin/Lib/files/EUKN/2014/12-she-accessibility-based-business-models-for-peer-to-peer-markets en.pdf

39. [Google Scholar]

40. Dubois, E., Schor, J., \& Carfagna, L. (2014). New Cultures of Connection in a Boston Time Bank. In J. Schor \& C. Thompson (Eds.), Practicing Plenitude. New Haven: Yale University Press. 95-124. [Google Scholar]

41. Edbring, E. G., Lehner, M., \& Mont, O. (2016). Exploring consumer attitudes to alternative models of consumption: motivations and barriers. Journal of Cleaner Production, 123, 5-15. [Google Scholar]

42. Ertz, M. (2020). Collaborative consumption, a buzzword that has gone conceptual: Three shades of the sharing economy. Oikonomics, 14(14), 1-14. [Google Scholar]

43. European Commission, 'A European agenda for the collaborative economy' (Communication) COM (2016) 356 final, (Collaborative $\quad$ Economy Communication). https:/eur-lex.europa.eu/legalcontent/EN/TXT/?uri=COM\%3A2016\%3A356\%3AFIN

44. European Commission. (2015). Communication from the Commission to the European parliament, the council, the European Economic and Social Committee and the Committee of the regions. 550 final. Upgrading the Single Market: more opportunities for people and business.

45. European Commission. (2016). Communication from the Commission to the European Parliament, the Council, the European economic and social committee and the committee of the regions. A European agenda for the collaborative economy, Brussels, 2.6.2016. COM (2016) 356 final.

46. European Parliament resolution of 29 October 2015 on new challenges and concepts for the promotion of tourism in Europe (2014/2241(INI). https://eur-lex.europa.eu/legal-content/EN/TXT/HTML/?uri=CELEX:52015IP0391\&from =EN

47. Evans, P. C., \& Gawer, A. (2016). The rise of the platform enterprise: A global survey. https://www.thecge.net/wpcontent/uploads/2016/01/PDF-WEB-Platform-Survey 01_12.pdf [Google Scholar]

48. Evelyn, K. (2020). It'sa racial justice issue': Black Americans are dying in greater numbers from Covid-19. The Guardian, 8. [Google Scholar]

49. Farmaki, A., Miguel, C., Drotarova, M. H., Aleksić, A., Časni, A. Č., \& Efthymiadou, F. (2020). Impacts of Covid-19 on peerto-peer accommodation platforms: Host perceptions and responses. International journal of hospitality management, 91, 102663. [Google Scholar]

50. Ferranti, L., D'Oro, S., Bonati, L., Demirors, E., Cuomo, F., \& Melodia, T. (2019, June). Hiro-net: Self-organized robotic mesh networking for internet sharing in disaster scenarios. In 2019 IEEE 20th International Symposium on" A World of Wireless, Mobile and Multimedia Networks"(WoWMoM) IEEE, 1-9. [Google Scholar]

51. Fitzsimmons, J.A. Consumer Participation and Productivity in Service Operations. Interfaces 15, 3 (1985), 60-67. [Google Scholar]

52. Frenken, K. (2017). Political economies and environmental futures for the sharing economy. Philosophical Transactions of the Royal Society A: Mathematical, Physical and Engineering Sciences, 375(2095), 20160367. [Google Scholar]

53. Gansky, L. (2010). The mesh: Why the future of business is sharing. Penguin. [Google Scholar]

54. Garud, R., Kumaraswamy, A., Roberts, A., \& Xu, L. (2020). Liminal movement by digital platform-based sharing economy ventures: The case of Uber Technologies. Strategic Management Journal. [Google Scholar]

55. Geissdoerfer, M., Savaget, P., Bocken, N.M. and Hultink, E.J., (2017). The Circular Economy-A new sustainability paradigm?. Journal of cleaner production, 143, pp.757-768. https://doi.org/10.1016/j.jclepro.2016.12.048

56. [Google Scholar]

57. Geissinger, A., Laurell, C., Öberg, C., \& Sandström, C. (2019). How sustainable is the sharing economy? On the sustainability connotations of sharing economy platforms. Journal of Cleaner Production, 206, 419-429. [Google Scholar] 
58. Gerwe, O., \& Silva, R. (2020). Clarifying the sharing economy: Conceptualization, typology, antecedents, and effects. Academy of Management Perspectives, 34(1), 65-96. [Google Scholar]

59. Gössling, S., \& Michael Hall, C. (2019). Sharing versus collaborative economy: how to align ICT developments and the SDGs in tourism?. Journal of Sustainable Tourism, 27(1), 74-96. [Google Scholar]

60. Graessley, S., Horak, J., Kovacova, M., Valaskova, K., \& Poliak, M. (2019). Consumer attitudes and behaviors in the technology-driven sharing economy: Motivations for participating in collaborative consumption. Journal of SelfGovernance and Management Economics, 7(1), 25-30. [Google Scholar]

61. Gruen, A. (2017). Design and the creation of meaningful consumption practices in access-based consumption. Journal of Marketing Management, 33(3-4), 226-243. [Google Scholar]

62. Hamari, J., Sjöklint, M., \& Ukkonen, A. (2015). The sharing economy: Why people participate in collaborative consumption. Journal of the Association for Information Science and Technology, 67(9), 2047-2059. https://10.1002/asi.23552 [Google Scholar]

63. Harvey, J., Smith, A., \& Golightly, D. (2017). Giving and sharing in the computer-mediated economy. Journal of Consumer Behaviour, 16(4), 363-371. https://doi.org/10.1002/cb.1499 [Google Scholar]

64. Heinrichs, H. (2013). Sharing economy: a potential new pathway to sustainability. GAIA-Ecological Perspectives for Science and Society, 22(4), 228-231. https://doi.org/10.14512/gaia.22.4.5 [Google Scholar]

65. Henry, M., Schraven, D., Bocken, N., Frenken, K., Hekkert, M., \& Kirchherr, J. (2021). The battle of the buzzwords: A comparative review of the circular economy and the sharing economy concepts. Environmental Innovation and Societal Transitions, 38, 1-21. [Google Scholar]

66. Hossain, M. (2020). Sharing economy: A comprehensive literature review. International Journal of Hospitality Management, 87, 102470. https://doi.org/10.1016/j.ijhm.2020.102470 [Google Scholar]

67. Hossain, M. (2021). The effect of the Covid-19 on sharing economy activities. Journal of Cleaner Production, $280(1), 124782$. [Google Scholar]

68. Hu, M. (Ed.). (2019). Sharing economy: making supply meet demand (Vol. 6). Springer. [Google Scholar]

69. Huang, L., Li, Y., Huang, X., \& Zhou, L. (2021). How social distance affects the intention and behavior of collaborative consumption: A study based on online car-hailing service. Journal of Retailing and Consumer Services, 61, 102534. [Google Scholar]

70. Huarng, K. H. (2018). Entrepreneurship for long-term care in sharing economy. International Entrepreneurship and Management Journal, 14(1), 97-104. https://doi.org/10.1007/s11365-017-0460-9 [Google Scholar]

71. Huckle, S., Bhattacharya, R., White, M., \& Beloff, N. (2016). Internet of Things, block chain and shared Economy applications. Procedia Computer Science, 98. https://10.1016/j.procs.2016.09.074 [Google Scholar]

72. Huefner, R. J. (2015). The sharing economy: Implications for revenue management. Journal of Revenue and Pricing Management, 14, 296-298. [Google Scholar]

73. Hunt, R. C. (2000). Forager food sharing economy: transfers and exchanges. Senri ethnological studies. [Google Scholar]

74. Jabłoński, A., \& Jabłoński, M. (2020). New economy business models in the concepts of big data, the sharing economy and the circular economy. In Social business models in the digital economy. Palgrave Macmillan, Cham. 51-88. [Google Scholar]

75. Jayakumar, J., Jayakrishna, K., Vimal, K. E. K., \& Hasibuan, S. (2020). Modelling of sharing networks in the circular economy. Journal of Modelling in Management. [Google Scholar]

76. Kaushal, L. A. (2018). The sharing economy and sustainability: a case study of India. Valahian Journal of Economic Studies, 9(2), 7-16. https://10.2478/vjes-2018-0013 [Google Scholar]

77. Kim, J., Yoon, Y., \& Zo, H. (2015). Why People Participate in the Sharing Economy: A Social Exchange Perspective. PACIS, 76. [Google Scholar] 
78. Koetsier, J. (2020). COVID-19 app economy: Instacart, Walmart, Costco Way Up, Uber and Lyft drop like rocks. https://www.forbes.com/sites/johnkoetsier/2020/03/24/covid-19-app-economy-instacart-walmart-costco-way-upuber-and-lyft-drop-like-rocks/\#234234f5551c [Google Scholar]

79. Lamberton, C. P., \& Rose, R. L. (2012). When is ours better than mine? A framework for understanding and altering participation in commercial sharing systems. Journal of marketing, 76(4), 109-125. [Google Scholar]

80. Lan, J., Ma, Y., Zhu, D., Mangalagiu, D., \& Thornton, T. F. (2017). Enabling value co-creation in the sharing economy: The case of mobike. Sustainability, 9(9), 1504. [Google Scholar]

81. Lawson, S. J., Gleim, M. R., \& Hartline, M. D. (2021). Decisions, decisions: variations in decision-making for access-based consumption. Journal of Marketing Theory and Practice, 1-17. [Google Scholar]

82. Lee, H. (2019). The effect of anti-consumption lifestyle on consumer's attitude and purchase intention toward commercial sharing systems. Asia Pacific Journal of Marketing and Logistics. Vol. 31 No. 5, pp. 1422-1441. [Google Scholar]

83. Light, A., \& Miskelly, C. (2019). Platforms, scales and networks: meshing a local sustainable sharing economy. Computer Supported Cooperative Work (CSCW), 28(3), 591-626. [Google Scholar]

84. Lutz, C., \& Newlands, G. (2018). Consumer segmentation within the sharing economy: The case of Airbnb. Journal of Business Research, 88, 187-196. [Google Scholar]

85. Markendahl, J., Hossain, M. I., Mccormick, K., Lund, T., Moller, J., \& Näslund, P. (2018). Analysis of sharing economy services: Initial findings from sharing cities Sweden. Nordic and Baltic Journal of Information and Communications Technologies, 1, 239-260. [Google Scholar]

86. Martin, C. J. (2016). The sharing economy: A pathway to sustainability or a nightmarish form of neoliberal capitalism?. Ecological economics, 121, 149-159. https://doi.org/10.1016/j.ecolecon.2015.11.027 [Google Scholar]

87. Mazzella, F., Sundararajan, A., d'Espous, V. B., \& Möhlmann, M. (2016). How digital trust powers the sharing economy. IESE Business Review, 26(5), 24-31. [Google Scholar]

88. Minami, A. L., Ramos, C., \& Bortoluzzo, A. B. (2021). Sharing economy versus collaborative consumption: What drives consumers in the new forms of exchange?. Journal of Business Research, 128, 124-137. [Google Scholar]

89. Mody, M., Suess, C., \& Lehto, X. (2019). Using segmentation to compete in the age of the sharing economy: testing a coreperiphery framework. International Journal of Hospitality Management, 78, 199-213. https://doi.org/ 10.1016/j.ijhm.2018.09.003. [Google Scholar]

90. Möhlmann, M. (2015). Collaborative consumption: determinants of satisfaction and the likelihood of using a sharing economy option again. Journal of Consumer Behaviour, 14(3), 193-207. [Google Scholar]

91. Molenaar, C. (2015). Why customers would rather have a smartphone than a car: Relationship retailing as an opportunity. Gower. [Google Scholar]

92. Morschheuser, B., Hamari, J., \& Maedche, A. (2019). Cooperation or competition-When do people contribute more? A field experiment on gamification of crowdsourcing. International Journal of Human-Computer Studies, 127, 7-24. [Google Scholar]

93. Muduli, K. K., Luthra, S., Kumar Mangla, S., Jabbour, C. J. C., Aich, S., \& de Guimarães, J. C. F. (2020). Environmental management and the "soft side" of organisations: Discovering the most relevant behavioural factors in green supply chains. Business Strategy and the Environment, 29(4), 1647-1665. [Google Scholar]

94. Muñoz, P., \& Cohen, B. (2017). Mapping out the sharing economy: A configurational approach to sharing business modeling. Technological Forecasting and Social Change, 125, 21-37. https://doi.org/10.1016/ j.techfore.2017.03.035 [Google Scholar]

95. Nižetić, S. (2020). Impact of coronavirus (COVID-19) pandemic on air transport mobility, energy, and environment: A case study. International Journal of Energy Research, 44(13), 10953-10961. [Google Scholar]

96. Olson, M. J., \& Kemp, S. J. (2015). Sharing Economy: An In Depth Look Its Evolution \& Trajectory Across Industries. Piper Jaffray Investment Research: March. [Google Scholar] 
97. Owyang, J. (2013). The three market drivers: causes for the collaborative economy. Retrieved from http://www.webstrategist.com/blog/2013/05/09/the-three-market-drivers-causes-for-the-collaborative-economy/

98. Oyedele, A., \& Simpson, P. (2017). Emerging adulthood, sharing utilities and intention to use sharing services. Journal of Services Marketing. Vol. 32 No. 2, pp. 161-174. [Google Scholar]

99. Perren, R., \& Grauerholz, L. (2015). Collaborative consumption. International Encyclopedia of the Social \& Behavioral Sciences, 4(2), 139-144. [Google Scholar]

100. Piscicelli, L., Ludden, G. D., \& Cooper, T. (2018). What makes a sustainable business model successful? An empirical comparison of two peer-to-peer goods-sharing platforms. Journal of cleaner production, 172, 4580-4591. https://10.1016/J.JCLEPRO.2017.08.170 [Google Scholar]

101. Probst, L., Frideres, L., Pedersen, B., \& Lidé, S. (2015a). Collaborative Economy. Collaborative production and the maker economy. Brussels: European Commission, Directorate-General Growth. [Google Scholar]

102. Probst, L., Frideres, L., Pedersen, B., \& Lidé, S. (2015b). Collaborative Economy. Crowdsolving. Brussels: European Commission, Directorate-General Growth. [Google Scholar]

103. Probst, L., Frideres, L., Pedersen, B., Lidé, S., et al. (2015c). Freemium model: zero marginal cost. Brussels: European Commission, Directorate-General Growth. [Google Scholar]

104. Räisänen, J., Ojala, A., \& Tuovinen, T. (2020). Building trust in the sharing economy: Current approaches and future considerations. Journal of Cleaner Production, 123724. https://doi.org/10.1016/j.jclepro.2020.123724 [Google Scholar]

105. Sanchez-Espiga, J., Fernandez-del-Rincon, A., Iglesias, M., \& Viadero, F. (2020). Influence of errors in planetary transmissions load sharing under different mesh phasing. Mechanism and Machine Theory, 153, 104012. [Google Scholar]

106. Scholz, T. (2014). Platform cooperativism vs. the sharing economy. Big data \& civic engagement, 47. [Google Scholar]

107. Schor, J. (2015). Getting Sharing Right. Contexts, 14(1), 14-15. . [Google Scholar]

108. Schor, J. (2016). Debating the sharing economy. Journal of Self-Governance and Management Economics, 4(3), 7-22. [Google $\underline{\text { Scholar] }}$

109. Schor, J. B. (2010). Plenitude: The New Economics of True Wealth. MP3 CD.

110. Schor, J. B. (2017). Does the sharing economy increase inequality within the eighty percent?: findings from a qualitative study of platform providers. Cambridge Journal of Regions, Economy and Society, 10(2), 263-279. [Google Scholar]

111. Schor, J. B., \& Wengronowitz, R. (2017). The new sharing economy: enacting the eco-habitus. Cohen MJ, Szejnwald Brown H., and Vergragt PJ, Social Change and the Coming of Post-consumer Society: Theoretical Advances and Policy Implications, Routledge, 246, 25-42. [Google Scholar]

112. Schor, J., \& Fitzmaurice, C. (2015). Collaborating and Connecting: The emergence of the sharing economy Handbook of Research on Sustainable Consumption Cheltenham, UK: Edward Elgar. 410-425. [Google Scholar]

113. Shortall, R., Mouter, N., \& Van Wee, B. (2021). COVID-19 passenger transport measures and their impacts. Transport Reviews, 1-26. [Google Scholar]

114. Schwanholz, J., \& Leipold, S. (2020). Sharing for a circular economy? an analysis of digital sharing platforms' principles and business models. Journal of Cleaner Production, 269, 122327. [Google Scholar]

115. Selloni, D. (2017). New forms of economies: sharing economy, collaborative consumption, peer-to-peer economy. In D. Selloni. CoDesign for Public-Interest Services. Springer, Cham, 15-26. [Google Scholar]

116. Skjelvik, J. M., Erlandsen, A. M., \& Haavardsholm, O. (2017). Environmental impacts and potential of the sharing economy, 2017554. Nordic Council of Ministers. [Google Scholar]

117. Strulak-Wójcikiewicz, R., \& Wagner, N. (2021). Exploring opportunities of using the sharing economy in sustainable urban freight transport. Sustainable Cities and Society, 68, 102778. https://doi.org/10.1016/j.scs.2021.102778 [Google Scholar]

118. Sutherland, W., \& Jarrahi, M. H. (2018). The sharing economy and digital platforms: A review and research agenda. International Journal of Information Management, 43, 328-341. [Google Scholar] 
119. Taeihagh, A. (2017). Crowdsourcing, sharing economies and development. Journal of Developing Societies, 33(2), 191-222. [Google Scholar]

120. Tardivo, A., Sánchez Martín, C., \& Carrillo Zanuy, A. (2020). Covid-19 impact in Transport, an essay from the Railways' system research perspective. [Google Scholar]

121. Tong, Y., Chen, L., \& Shahabi, C. (2017). Spatial crowdsourcing: Challenges, techniques, and applications. Proceedings of the VLDB Endowment, 10(12), 1988-1991. [Google Scholar]

122. Tong, Y., Zhou, Z., Zeng, Y., Chen, L., \& Shahabi, C. (2020). Spatial crowdsourcing: a survey. The VLDB Journal, 29(1), 217250. [Google Scholar]

123. Toni, M., Renzi, M. F., \& Mattia, G. (2018). Understanding the link between collaborative economy and sustainable behaviour: An empirical investigation. Journal of Cleaner Production, 172, 4467-4477. https://doi.org/10.1016/ j.jclepro.2017.11.110 [Google Scholar]

124. Vaskelainen, T., Münzel, K., Boon, W., \& Frenken, K. (2021). Servitisation on consumer markets: entry and strategy in Dutch private lease markets. Innovation, 1-20. [Google Scholar]

125. Vaughan, R., \& Hawksworth, J. (2014). The sharing economy: how will it disrupt your business? Megatrends: the collisions. London: PriceWaterhouse\& Cooper. [Google Scholar]

126. Wagner, N., \& Strulak-Wojcikiewicz, R. (2020). Concerns about the technology used by collaborative platforms-a challenge for managers. Procedia Computer Science, 176, 2536-2545. https://doi.org/10.1016/ j.procs.2020.09.319 [Google Scholar]

127. Wasserbaur, R., Sakao, T., Söderman, M. L., Plepys, A., \& Dalhammar, C. (2020). What if everyone becomes a sharer? A quantification of the environmental impact of access-based consumption for household laundry activities. Resources, Conservation and Recycling, 158, 104780. [Google Scholar]

128. WEF. (2013). Young Global Leaders Sharing Economy Dialogue Position Paper World Economic Forum (WEF). Retrieved from: http://www3.weforum.org/docs/WEF_YGL_CircularEconomyInnovation_PositionPaper_2013.pdf (08-01-2022). [Google Scholar]

129. WEF. (2014). Towards the Circular Economy: Accelerating the scale-up across global supply chains: World Economic Forum (WEF). Retrieved from: http://www3.weforum.org/docs/WEF ENV TowardsCircularEconomy Report 2014.pdf (08-012022). [Google Scholar]

130. Willison, T. (2020). Sharing During Pandemic-How TTL is dealing with C19 [WWW Document]. Tor. Tool Libr. URL https://www. torontotoollibrary. com/blogs/post/sharing-during-pandemic. [Google Scholar]

131. Wu, X., \& Zhi, Q. (2016). Impact of shared economy on urban sustainability: from the perspective of social, economic, and environmental sustainability. Energy Procedia, 104, 191-196. https://doi.org/10.1016/j.egypro. 2016.12.033 [Google Scholar]

132. Yang, S., Song, Y., Chen, S., \& Xia, X. (2017). Why are customers loyal in sharing-economy services? A relational benefits perspective. Journal of Services Marketing. [Google Scholar]

133. Yaraghi, N., \& Ravi, S. (2017). The current and future state of the sharing economy. Available at SSRN 3041207. [Google Scholar]

134. Yoon, S. J. (2021). Role of Social Capital and Consumer Citizenship on Sharing Economy Participation on O2O Retail Platforms. Journal of Distribution Science, 19(10), 55-64. [Google Scholar]

135. Zhang, J., Hayashi, Y., \& Frank, L. D. (2021). COVID-19 and transport: Findings from a world-wide expert survey. Transport policy, 103, 68-85. [Google Scholar]

136. Zhu, X., \& Liu, K. (2020). A systematic review and future directions of the sharing economy: business models, operational insights and environment-based utilities. Journal of Cleaner Production, 290, 125209. https://doi.org/10.1016/j.jclepro.2020.125209 [Google Scholar]

137. Google trends. The number of visits to sharing platforms, 2020. https://trends.google.com/trends/?geo=US 